\title{
Teaching
Methods
}

\section{Experiential Learning through Partnership: A Case Study of a Collaborative, Hands-on Program to Teach High School Students Organic Farming}

\author{
Erin M. Silva ${ }^{1,3}$ and Geraldine Muller ${ }^{2}$
}

ADDITIONAL INDEX WORDs. participatory learning, organic agriculture, K-12 education

\begin{abstract}
SUMMARY. In 2008, a collaborative project was initiated between the La Farge School District (La Farge, WI), University of Wisconsin-Madison College of Agriculture and Life Sciences, Organic Valley Cooperative Regions Organic Producers Pools (La Farge, WI), and Kickapoo Valley Reserve (La Farge, WI). The overarching mission of the program is to build a sustainable, hands-on educational farm and corresponding curriculum to teach organic agriculture principles to high school students and increase the number of students entering agriculture-related professional fields. Secondary goals of the project include delivering locally grown organic produce and related organic agriculture educational opportunities to the broader community. To achieve these goals, a multifaceted student internship program was created that includes a range of experiential learning opportunities for students. With the participation of each of the project partners, about ten students per year engage in the field production of certified organic vegetables, participate in field trips to sites related to organic agriculture, and distribute the produce to the school and the broader community. Through the integration of these activities, students are taught key principles of successful organic management, including ecologically based disease, weed, and insect management, development of a soil fertility plan, market analysis and its implications of crop selection, and determination of costs of production. In the face of both successes and challenges, through informal evaluation of students and the project team, the program continues to develop each year.
\end{abstract}

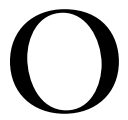
rganic agriculture production has expanded to 4.8 million acres in the United States, with $2,643,221$ acres of organic cropland and 156,615 acres of

We would like to thank the Kickapoo Valley Restoration Fund for funding this project.

${ }^{1}$ Department of Agronomy, University of WisconsinMadison, 1575 Linden Drive, Madison, WI 53706

${ }^{2}$ School District of La Farge, 301 W. Adams Street, La Farge, WI

${ }^{3}$ Corresponding author. E-mail: emsilva@wisc.edu. vegetable crops [U.S. Department of Agriculture (USDA), 2008]. The market for organic food continues to grow, with sales experiencing a $7.7 \%$ increase from 2009 to 2010 , up from a $5.1 \%$ increase from 2008 to 2009 [Organic Trade Association (OTA),
2011]. This growth rate vastly outpaces the $0.6 \%$ growth rate of total food sales during the similar time period, bringing organic to $4 \%$ of total food sales (OTA, 2011). Wisconsin continues to experience growth in the organic sector with respect to both farming and processing operations. As of 2008, Wisconsin ranked second in the nation after California in the number of organic farms, with 1222 certified organic operations, of which 254 grow vegetables (Silva et al., 2012). Wisconsin ranks sixth in the nation for the total organic product sales at \$132.8 million (Silva et al., 2012).

With the growth in the organic marketplace, new employment opportunities arise. According to the U.S. Bureau of Labor Statistics, employment for agricultural and food scientists is anticipated to expand $10 \%$ in 2010-20, with employment opportunities for agricultural and food science technicians estimated to increase $7 \%$ (U.S. Bureau of Labor Statistics, 2012). Within the organic agriculture sector, a 2010 survey by OTA (2011) reported $40 \%$ of the organic companies experienced positive full-time employment growth. Fortysix percent of the survey respondents anticipated a further increase in hiring in the upcoming years and $50 \%$ of respondents expected employment to remain steady.

A growing consensus exists among agricultural educators as to the importance of practical experience and hands-on learning to effective agricultural pedagogy. University of California-Davis used the Delphi survey technique to determine, from a subset of agricultural academics at that institution, the type of activities that should be included in an undergraduate sustainable agriculture major (Parr et al., 2007). Using the guiding principles of this technique, the authors anonymously gathered the options of sustainable agriculture curriculum experts through a series of structured questionnaires, with each subsequent questionnaire summarizing the responses of the previous questionnaire through a process of

\begin{tabular}{llll}
\hline $\begin{array}{l}\text { Units } \\
\begin{array}{l}\text { To convert U.S. to SI, } \\
\text { multiply by }\end{array}\end{array}$ & U.S. unit & SI unit & $\begin{array}{l}\text { To convert SI to U.S., } \\
\text { multiply by }\end{array}$ \\
\hline 0.4047 & acre(s) & ha & 2.4711
\end{tabular}


controlled feedback. Respondents emphasized the importance of linking classroom theory to practice, suggesting the adoption of innovative teaching techniques to achieve this goal. Applying classroom knowledge to field settings was specifically highlighted, including on-farm experiences such as internships, student farms, farm and industry visits, and conversations with farmers. At North Carolina State University, Schroeder et al. (2006) summarized student perceptions of the organic and sustainable agriculture programs, with students reporting as the most valuable aspects of the program the engagement in hands-on learning activities, participation in a working farm, interaction with local farmers, and farm visits.

These findings return full-circle to the education philosophies of pedagogical pioneers of the 20th century; in 1916, John Dewey, a prominent educational scholar in the United States, argued that experience and hands-on projects were essential to ensure successful learning outcomes (Giles and Eyler, 1994). Similarly, Liberty Hyde Bailey, the founding dean of the College of Agriculture at Cornell University, stressed the importance of hands-on learning experiences (Trelstad, 1997). More recently, Knobloch (2003) integrated the philosophies of Dewey, Bailey, and other key scholars into what he refers to as the four pillars of experiential learning in agricultural education: learning by doing, learning in real-life context, learning through projects, and learning by solving problems.

To address the need to increase the number of experiential learning opportunities for students wishing to engage in agricultural education and enter agriculture-related fields, the Farm Links program was initiated in 2007. From its inception, Farm Links was designed as a collaboration between a public kindergarten through grade 12 (K-12) school district (La Farge School District, La Farge, WI), a large land-grant university (University of Wisconsin-Madison), a state government and Native American Nation Memorandum of Understanding (Kickapoo Valley Reserve, La Farge, WI), and an organic farmer cooperative [Organic Valley Cooperative Regions Organic Producer Pools (CROPP), La Farge, WI]. The objectives of the program are several-fold: to provide students with an experiential educational opportunity in organic agriculture; to incorporate introductory organic farming principles into school curriculum and lesson plans; to provide students with a meaningful summer employment opportunity; to expose students to career paths intersecting with organic agricultural production, highlighting the viability of this career path and increasing the number of students entering the local agriculture industry; and through the students, to bring organic agriculture principles to the broader community. This article details the development of the Farm Links program over a 4 -year period and its continued progress.

\section{Materials and methods}

Begun in 2007, the project was initiated by and continues to be supported through competitive funds received from the Kickapoo Valley Reforestation Fund. This fund supports projects that enhance the ecological, economic, and social well being of the Kickapoo Valley (located in the southwestern corner of Wisconsin) and its residents, within which reside the La Farge School District and its students. Created in 1973, the fund was established through a bequest to the University of Wisconsin Foundation by Ralph Nuzum, a longtime businessman and resident of the Kickapoo Valley, with the intention the fund "...be used to support model comprehensive land use, forestation, conservation, and rehabilitation projects involving an interdisciplinary University team cooperating with broadly representative citizens, groups and local leaders in the Kickapoo Valley." To remain true to this intent, the Farm Links program's mission is to create a sustainable school-based program that supports organic and locally grown products while teaching children, adults, and the community about the benefits of organic farming and integrating the products of this endeavor into the local food system.

The location of this project is uniquely suited for this program. La Farge, WI, is a small, rural farming community of 746 residents. The southwest region within Wisconsin (Vernon County) where the town of La Farge is located has a long history of organic production; home of the CROPP national headquarters, Vernon County has the highest density of organic farms in the state (Silva et al., 2012). Organic and sustainable farming methods are vital to the long-term viability of farming the hills and valleys of this region and have provided employment opportunities for local citizens. CROPP is a nationally recognized leader in the organic marketplace, with over 1200 farmer members and over 500 employees (E. Lange, personal communication).

The Farm Links project engages multiple project partners, each of whom brings unique physical and intellectual resources to the project. Teachers from La Farge School District lead students through the daily activities of the program. CROPP provides a 1 -acre plot on its national headquarters' certified organic grounds that is farmed by the Farm Links students and is within walking distance of another organic farming demonstration site. A scientist specializing in organic agricultural production from the University of WisconsinMadison (UW-Madison) College of Agriculture and Life Sciences, located $\approx 2 \mathrm{~h}$ east of La Farge, serves as the primary university partner on the project. With expertise in organic production, she provides guidance regarding appropriate crop and variety selection, pest management strategies, organic production techniques, and postharvest management. The executive director of the Kickapoo Valley Reserve provides insight on effectively linking with the local community and ensuring meaningful fulfillment of the fund's mission.

The components of the internship program can be divided into three primary categories: the experiential on-farm field and field trip component; the classroom component; and the community outreach component. These three components are discussed below.

The FIELD AND FIELD TRIPS. The on-farm internship program is the core of the Farm Links project. With money provided by the Kickapoo Valley Restoration Fund, between 7 and 12 students from grades 9 and 12 are accepted into the program each year and hired into a paid internship lasting through the summer months. The team members from the La Farge School District lead the recruitment and hiring of the interns from amongst the middle and high school students in the district. Thus far, the program 
has been able to hire all of the students that applied each year of the program. For the duration of the summer internship, the students work three half-days per week, equating to an average of 10-12 h each week and participate for $3-4 \mathrm{~h}$ per week in various enrichment activities described below.

Planning of the field activities associated with the project is a collaborative effort undertaken by all the team members. The project team holds two strategy meetings (fall and spring of each year of the project) to discuss appropriate crops for the project. In previous years of the project, a diversity of crops was grown throughout the 2008-11 growing seasons. Several factors determine crop selection: 1) the ability to integrate the produce into the CROPP headquarters and La Farge school kitchens, as well as into other activities; 2) the ability to grow the crop within the summer time frame when the students are actively in the field and do not have extracurricular activity commitments; and 3) the potential for moderate to minimal pest pressures on the crops. Selected crops have included: basil (Ocimum basilicum), salad mix [including lettuce (Lactuca sativa), kale (Brassica oleracea var. acephala), and spinach (Spinacia oleracea)], winter squash (Cucurbita moschata), popcorn (Zea mays var. everta), and sunflower (Helianthus annuus) in 2008; green pepper (Capsicum annuum) and eggplant (Solanum melongena) in 2009; green pepper and green bean (Phaseolus vulgaris) in 2010; and green pepper, winter squash, and pumpkin (Cucurbita maxima) in 2011. All crops were grown using certified organic production practices in compliance with the USDA National Organic Program, with the appropriate records maintained by the students and instructors.

During 2010, a small chest freezer was donated to the program and placed in the La Farge school kitchen. The acquisition of the freezer was instrumental in the ability to integrate the produce into school lunches. With processing of the produce occurring during the summer months and storing the prepared produce in the freezer, the produce can be grown while the interns are active in the field and used by the La Farge school cafeteria during the school year.
To further inform students as to potential careers in agriculture, field trips throughout Wisconsin to various agriculture-related enterprises are organized. With the high density of organic farms in the surrounding area, many opportunities exist for the students to interact with a wide range of farming operations and $\mathrm{CO}^{-}$ operatives ranging from permaculture systems to community supported agriculture sites. One day each week during the summer internship program, site visits are scheduled to area farms, businesses, and community stakeholders. Visits may include: the organic certification department at CROPP, focusing on organic certification; CROPP farms producing transplants, bedding plants, and a variety of produce, to learn about organic pest management and production practices; the CROPP produce distribution center to review the USDA produce grading requirements and marketing parameters for organic produce; a community supported agriculture (CSA) farm to learn about operating an organic CSA; UWMadison organic field days to learn about research conducted to benefit organic production systems; the Willy Street Grocery Cooperative in Madison, WI, to learn about the marketing of organic products; the Milky Way Café at CROPP headquarters to assist in the creation of recipes using produce from the garden under the guidance of their chef; and the La Farge school kitchen food service staff and coordinator to learn about the complexities of integrating local produce into school cafeterias.

Instruction. Two teachers from the La Farge School District serve roles as project coordinator and instructor. The classroom instruction focuses on the practical applications of organic and sustainable farming principles, business management, and marketing, thus providing the opportunity to integrate organic farming into the more traditional focused courses of study within the agriculture department at the high school. The Farm Links project is available to instructors for integration into the curriculum in other subject areas such as agricultural business, food and consumer education, and science. By integrating the concepts of the Farm Links more broadly into the school curriculum, teachers created new opportunities for the instruction of sustainability concepts throughout multiple subjects.

Strengthening this integration of the summer experiences to the school year curriculum, the National Honor Society (NHS) of La Farge High School has adopted Farm Links as a leadership project. The Farm Links project team, along with four teaching staff and the school principal, work with NHS to incorporate the Farm Links program into general curriculum classes for the upcoming summer and school year.

University of Wisconsin has also been involved in various aspects of both classroom and field instruction. Using a farm financial analysis program developed by UW-Madison for organic vegetable producers as a learning tool, the UW-Madison team member meets with the Farm Links students during the school year to introduce concepts of farm finances, discuss the determination of the costs of production, and train the students to use the tool to evaluate the project's farm finances. This activity allows students to directly participate in the same decision-making processes that growers undertake to maintain a successful, sustainable, and profitable business. With three visits throughout the growing season each year, the UW-Madison scientist travels to La Farge to meet with the students to discuss various aspects of field operations, addressing topics such as crop selection, pest management, fertility, and postharvest management. Additionally, in the most recent year of the project, UW-Madison undergraduate students involved in the UWMadison organic agriculture program meet with the Farm Links students to discuss their personal experiences with agricultural opportunities in higher education.

Community involvement. The involvement and enthusiasm of the local community surrounding the La Farge School District remains a key aspect to the continued sustainability of the project. During the first year of the program, initial community interactions occurred through relationships developed with CROPP employees. Throughout the first summer of the program, students were partnered with individuals at CROPP in careers of interest to the students, 
including research and development, culinary fields, and administration. In the second and third year of the program, additional community ties were forged by the project through participation in community-wide events. Farm Links students now take part in an event called the "Harvest Challenge," using produce grown on their farm plot to highlight outcomes of the Farm Links program. This annual event seeks to create healthier students and stronger rural economies by linking school food service programs with local food producers. The challenge involves a menu planning and cooking contest for high school students highlighted by the inclusion of local produce into school lunch programs. The competition pairs teams of Vernon County high school students with local chefs to design and serve a healthy school meal that would appeal to students while remaining achievable to produce in the school kitchen. The teams are challenged to use local foods, meet the nutrition guidelines of the National School Lunch Program, and keep the cost to less than $\$ 1.00$ for food per meal. Through participation in this event, students improve their understanding of the "field to fork" connection of food production to consumption, particularly as it relates to the specific challenges of increasing the use of locally grown produce in school cafeterias.

Community outreach opportunities also provide Farm Links students with experience in developing and delivering messages about the Farm Links program and organic agriculture to the public. Students present the project to numerous audiences, including CROPP's monthly cooperative membership meetings, the La Farge School Board, and the Kickapoo Valley Reserve board. Students presented an informational poster at the Organic Farming Conference in La Crosse, WI, as part of a youth forum in Feb. 2011; this conference, attended by farmers, educators, researchers, and advocates, draws 3000 participants each year. The interns in the Farm Links program are also responsible for writing and submitting weekly articles to the local newspaper. Throughout this series of articles, the community is informed and updated on the progress of the project

\section{Results}

A summary of Farm Link's activities is presented in Table 1. An ongoing challenge of the program is the conflict of creating a summer internship program for students who are enrolled in a traditional public school and the need to conduct planning and field operations beyond that time frame. During the first 2 years of the project, students did not participate in the program during the academic year. Because of the desire to expose students to the entire range of activities required for a successful farming operation, in the most recent years of the program, students participate in 20-30 h of related activities during the school year. However, participation for this longer time frame required a significant commitment from students who were often engaged in conflicting extracurricular activities.

The project also has faced production and marketing challenges over the seasons. These challenges include: poor quality fruit due to flooding; identification of markets for produce not meeting the highest USDA grade standards ("seconds"); lack of a predetermined purchasing agreement for the produce; and lack of transportation and on-site cold storage (during the initial years of the program). Postharvest quality issues were resolved through obtaining a cooler to store the produce. Solutions for marketing the small volume of produce generated by the project are still being explored.

One of the most significant challenges remaining for the program involves institutionalizing the financial support for the program. From its inception, the Kickapoo Valley Restoration Fund has funded the project. However, these funds are competitive, and a new proposal must be considered each year to receive funds. Unfortunately, because of the aforementioned conflicts of student schedules as well as diverse education goals, designing the operation to be completely self-sufficient from the sales of produce will continue to be a challenge.

\section{Discussion}

The importance of hands-on, experiential learning opportunities is increasingly recognized as having a vital role in student learning outcomes, particularly in applied, systems-based subject areas. Creating experiences that require project partners with broad expertise in an economic resourcescare environment is increasingly difficult. The Farm Links program serves as one model to bring a diverse group of partners together to create such an opportunity for students. By pooling the resources and skills of each of the project team members, students are involved in both hands-on activities and field trips that expose them to a wide array of practical knowledge and career paths.

The issue of balancing student needs with the creation of a profitable business model remains a difficult compromise. Ideally, the project strives to be student-driven; using the tools provided through the project, the students systematically work through the thought processes required to create a financially sustainable certified organic operation. Through this opportunity, students are able to develop the integrative, critical-thinking skills that will benefit them as they transition from high school to other endeavors. With this freedom, students will most likely make choices that might not be optimal as they learn through experience, despite the availability of historical project information. A certain degree of budgetary flexibility must exist to allow for this student learning curve.

In addition, the focus of the project on the summer months and the need to cultivate less productionintensive crops excludes some of the more profitable crop choices available to Wisconsin farmers. Because of the lower supply in relation to demand, produce available at the beginning and the end of the growing season tend to provide a higher profit margin. Also, again because of the desire to focus much of the production decision-making on the students, crops requiring less complicated management are selected for the project. Thus, it is more difficult to incorporate into the organic farm plan an array of crops that would be optimal from a financial standpoint.

To overcome some of the budgetary challenges, one option being explored is the incorporation of volunteer labor at the farm site. The use of volunteer labor ("worker shares") is quite common on CSA farms, and thus would provide students with 


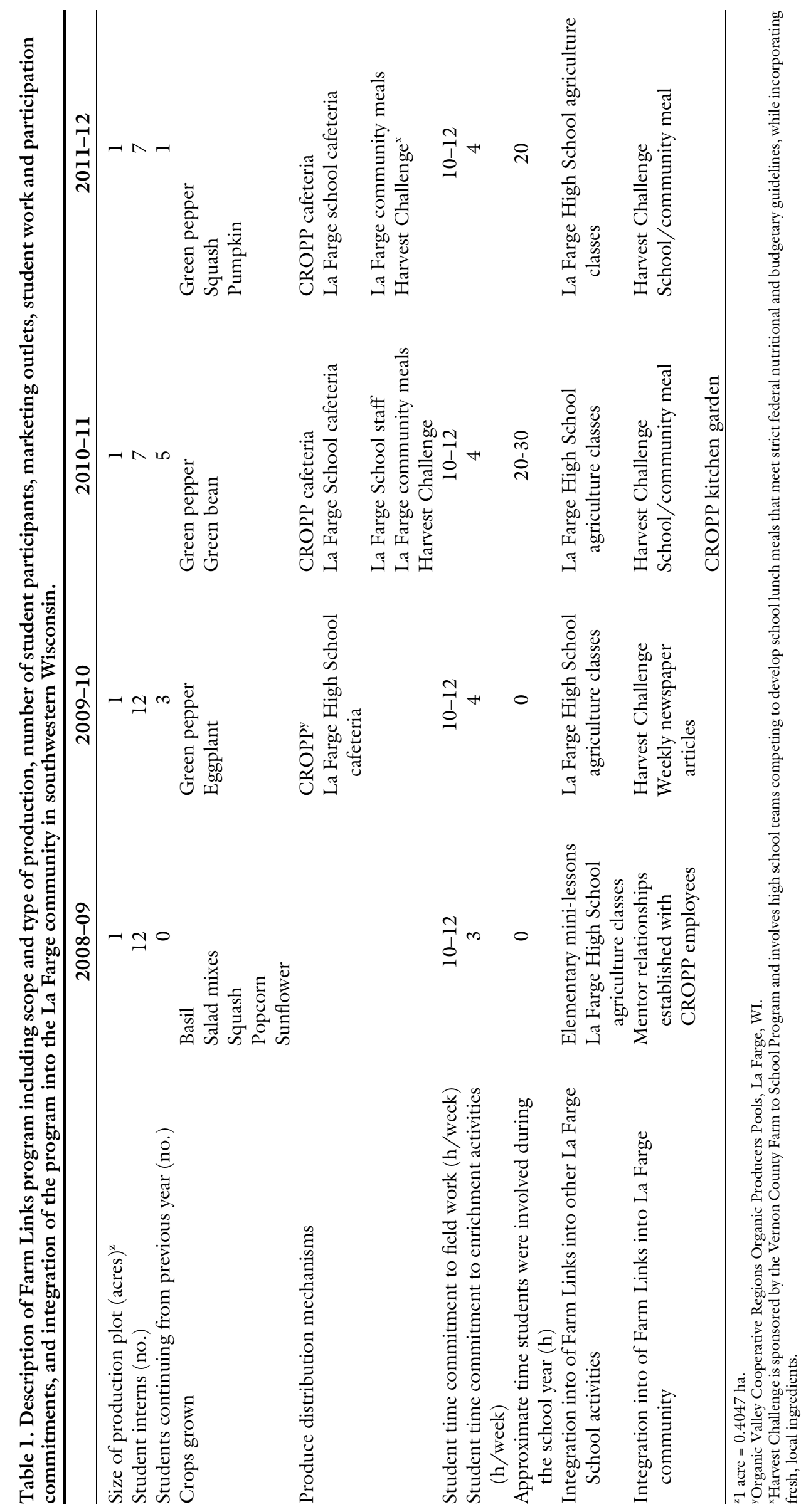


experience in a different aspect of farm management. However, challenges could arise from the coordination and management of a volunteer labor force and to this date the project team has not actively pursued this option.

In future years, the project team will pursue several new activities and partnerships. A stronger partnership with the local county Cooperative Extension offices will be forged. Through this collaboration, the La Farge-based team will have additional resources to offer production and marketing expertise. In addition, assistance from Cooperative Extension partners will facilitate the expansion and duplication of this program to other interested school districts.

To better evaluate project impact, the UW-Madison project partner will receive the appropriate Institutional Review Board approval to systematically track student changes in attitudes, knowledge, and perception during their involvement in the program. With this information, the project team will be able to more effectively measure learning outcomes and document the impact of the program on student career choices and their perceptions of agricultural systems.

\section{Conclusion}

The Farm Links program has succeeded in many of the aforementioned proposed objectives it sought to achieve. Through relationships built with various leaders and representatives of the Kickapoo Valley as well as the research community of UW-Madison, students are able to access valuable local history, knowledge, tradition, and culture related to organic and sustainable agriculture. Applying this knowledge within a locally supported program creates opportunities for personal and academic growth. The project supports local stewardship and creates a model to bring locally produced food to local kitchens, businesses, and CSAs. The community is actively involved in following progress of the Farm Links program through local news media, community dinners and visits to the 1 -acre farm plot. An informal indicator of success of the program is the continued involvement of the students both in the Farm Links program and in agricultural fields after graduation. Interns working in the program often return to the program in subsequent summers, and, among the first cohort of students engaged in the program, three have chosen to pursue agriculturerelated majors at colleges and universities. The program continues to develop each year as new opportunities develop and student interests change.

\section{Literature cited}

Giles, D.E. and J. Eyler. 1994. The theoretical roots of service-learning in John Dewey: Toward a theory of service-learning. Michigan J. Community Serv. Learning $1: 77-85$.
Knobloch, N.A. 2003. Is experiential learning authentic? J. Agr. Educ. 44:2234 .

Organic Trade Association. 2011. U.S. organic industry overview. 24 Sept. 2012. <http://www.ota.com/organic/ mt.html>.

Parr, D.M., C.J. Trexler, N.R. Khanna, and B.T. Battisti. 2007. Designing sustainable agriculture education: Academics' suggestions for an undergraduate curriculum at a land-grant university. Agr. Human Values 24:523-533.

Schroeder, M.S., N.G. Creamer, H.M. Linker, J.P. Mueller, and P. Rzewnicki. 2006. Interdisciplinary and multilevel approach to organic and sustainable agriculture education at North Carolina State University. HortTechnology 16:418426.

Silva, E.M., L. Paine, M. Barnidge, C. Carusi, and R. McNair. 2012. Organic agriculture in Wisconsin: 2012 status report. 18 Oct. 2012. <http://www.cias. wisc.edu/crops-and-livestock/organicagriculture-in-wisconsin-2012-statusreport $/>$.

Trelstad, B. 1997. Little machines in their gardens: A history of school gardens in America, 1891 to 1920 . Landscape J. 16: 161-173.

U.S. Bureau of Labor Statistics. 2012. Occupational outlook handbook. 18 Oct. 2012. <http://www.bls.gov/ooh/ home.htm $\geq$.

U.S. Department of Agriculture. 2008. Organic production. 18 Oct. 2012. $<$ http://www.ers.usda.gov/dataproducts/organic-production.asp $\mathrm{x}>$. 